\title{
By Order of George W. Bush: The Unilateral Directives of a Unilateralist President
}

\author{
Graham G. Dodds
}

This article examines George W. Bush's unilateral presidential directives, including executive orders, proclamations, and executive memoranda. It seeks to ascertain whether his use of such directives was as radical as his critics claimed and whether it was in keeping with that of previous presidents or departed from established practices. I divide Bush's more noteworthy directives into three categories (regular, rare, and remarkable), and I consider several directives within each category. I find that while some of Bush's unilateral directives were radically new and controversial both politically and constitutionally, many of his directives were based on earlier presidents' precedents.

George W. Bush's presidency was controversial for many different reasons. Whatever our feelings may be about the man and his policies, Bush often acted much as the "energetic" executive that Alexander Hamilton famously advocated in Federalist Paper \#70. Indeed, one of the more noteworthy aspects of Bush's presidency was his concerted effort to assert the powers and prerogatives of the presidency in order to enhance the strength of the executive (Pfiffner 2008). And in conducting his energetic, activist presidency, Bush often relied on unilateral presidential directives. As Kenneth Mayer observed, “some of President Bush's most controversial actions have stemmed directly from assertions of unilateral constitutional powers" (Mayer 2004, 11).

Bush was not the first president to use unilateral directives. Indeed, every other president (except William Henry Harrison, whose presidency lasted one month) has used unilateral directives. But it was not immediately clear that Bush would use unilateral directives so extensively or controversially. In a sense, at the start of his presidency Bush faced a choice that all presidents face. One option was a Neustadtian presidency, in which he would govern through compromise, bargaining, and persuasion (Neustadt 1960). The other option was to lead unilaterally and decisively, by pushing the limits of executive power and by making extensive use of unilateral directives. There were good reasons to think that Bush might make the first choice, including his record as Governor of Texas and his campaign rhetoric in 2000 about being a uniter and trying to work across party lines. Additionally, as Richard Pious has argued, unilateral presidential powers are a "poison" that inevitably hurts presidents who use them (Pious 1974). But

GRAHAM G. DODDS is an assistant professor of political science at Concordia University.

The American Review of Politics, Vol. 29, Fall, 2008: 197-213

(C)2008 The American Review of Politics 
other factors-including perhaps Bush's personality, his advisors, a closely divided Congress, and the exigencies of 9/11 and terrorism-suggested that he would often use unilateral directives. Ultimately, Bush settled on the second option. Bush's choice was not exceptional. As Ryan Barilleaux argues, presidents since Watergate have increasingly turned to unilateral power (Barilleaux 1988). But the degree to which Bush relied on unilateral powers was perhaps exceptional.

According to a 1998 congressional study, there are two dozen different types of unilateral presidential directives (Relyea 1988). These include familiar devices like executive orders and proclamations, as well as more esoteric tools like presidential memoranda and determinations (Cooper 2002). And in recent years, the number and type of unilateral directives has grown, with the addition of Homeland Security directives, for example. By and large, these directives are written documents issued by presidents to control the actions of the executive branch. They are rooted either in statute or in the president's own constitutional authority. While these directives can be reversed by the judiciary or the legislature, they seldom are (Mayer 1999, 448; Moe and Howell 1999a, 175; Edwards 1999).

For several years now, politicians, journalists, and jurists have been debating the propriety of some of Bush's unilateral directives. And the general topic of unilateral presidential directives has also started to attract the interest of political scientists and other academics (e.g., Mayer 2001; Cooper 2002; Howell 2003; Warber 2006; and Rodrigues 2008). This article seeks to place Bush's use of unilateral directives into a broader context and to ascertain whether and how they departed from established practices and what their implications may be for the future use of such directives and for the presidency.

As of Election Day, 2008, Bush had issued a total of 915 proclamations, 280 executive orders, and dozens of memoranda and other directives during his time as president. As the table indicates, Bush's numbers of executive orders and proclamations are similar to those of the five administrations that preceded his first administration. Quantitatively, then, Bush's issuance of unilateral directives appears to be very much in line with that of other recent presidents.

However, a quantitative approach to comparing Bush's directives with those of other presidents is problematic for several reasons. First, there is no complete compendium of all presidential directives. Thousands of early presidents' directives have been lost forever, and many directives are secret and classified and hence inaccessible. Sometimes secret directives are assigned a public number, but other times there is not even a number to indicate their existence. Also, the distinctions between and among some directives, like executive orders and proclamations, are inexact, so counting 


\section{Table 1. Presidential Executive Orders and Proclamations by Administration}

\begin{tabular}{lcc}
\hline $\begin{array}{l}\text { Presidential } \\
\text { Administration }\end{array}$ & $\begin{array}{c}\text { Number of } \\
\text { Executive Orders }\end{array}$ & $\begin{array}{c}\text { Number of } \\
\text { Proclamations }\end{array}$ \\
\hline G.W. Bush (II)* & 107 & 453 \\
G.W. Bush (I) & 173 & 462 \\
B. Clinton (II) & 164 & 435 \\
B. Clinton (I) & 200 & 443 \\
G.H.W. Bush & 166 & 589 \\
R. Reagan (II) & 168 & 643 \\
R. Reagan (I) & 213 & 475 \\
*As of Election Day 2008. & & \\
Sources: Executive order counts from The Federal Register, www.archives.gov/federal-register/ \\
executive-orders/disposition.html. Proclamation counts from: The American Presidency Project, \\
www.presidency.uscb.edu/proclamations.php.
\end{tabular}

different types of directives is problematic. And while there is fairly good data on executive orders and proclamations since the FDR, there is not yet any reliable tabulation of presidential memoranda and other unilateral directives. ${ }^{1}$ Therefore, as one author put it, "mere counting" of unilateral directives is problematic and insufficient for most purposes (Cooper 2002, 13).

Moreover, aside from problems with the availability and reliability of data, there is the issue of significance. Although unilateral executive directives can be dramatic, they are usually not very important (Mayer and Price 2002; Howell 2003, 83; Warber 2006, 55, 57). Indeed, the majority of Bush's unilateral directives, like the majority of previous president's unilateral directives, were not especially significant. Most of them addressed matters of administrative minutae or served merely hortatory purposes. For example, Bush issued dozens of fairly mundane proclamations for foreign trade: to implement trade agreements with individual countries and larger regions, to modify duties, and to harmonize tariffs. And in November 2007, Bush issued an executive order to open military airspace off the east coast in order to ease congestion associated with travel for the Thanksgiving holiday. That directive was unprecedented, and it may have eased travel for millions of people, but it does not seem to rise to the level of great importance. ${ }^{2}$

Given the paucity of scholarship on the topic, the problems of definition and incomplete data, and the question of distinguishing directives that are significant from those that are not, my own approach here is qualitative and subjective. This seems to be the best way to proceed, and, to their credit, the authors of one of the rational choice accounts of unilateral presidential action concede that a broadly contextual or historical institutionalist 
approach might be useful (Moe and Howell 1999b, 869). In order to assess Bush's usage of unilateral directives and its impact on his legacy and American politics, I divide Bush's noteworthy directives into three alliterative categories - regular, rare, and remarkable — and I examine several directives within each category. These categories are inexact, and my selection criteria are based only on my own reading of the scant scholarly literature, news reports, and the directives themselves, but this categorization nevertheless demonstrates the extent to which Bush's noteworthy directives adhered to and departed from the norm.

\section{Regular}

Again, most presidential unilateral directives are not very important, and this was certainly true of most of Bush's directives. In that respect, his overall use was more or less regular. But even among the unilateral directives that do have a significant or dramatic impact on politics or public policy, many uses are fairly common or typical, and many of Bush's directives exhibited this regularity, too. This may be seen by considering some of Bush's directives concerning abortion, organized labor, the environment, and regulation.

On his fourth day in office, on the twenty-eighth anniversary of Roe $v$. Wade, Bush issued an executive order to block federal funding for international family planning groups that provided abortion-counseling services. Bush's order effectively reversed the pro-choice policy that Bill Clinton had established via executive order in 1993 and reverted to the Reagan-Bush pro-life policy, also known as the "Mexico City gag rule," which was established via executive order in 1984 (Branum 2002, 44). Several months later, the U.S. House tried but narrowly failed to overturn Bush's policy (Lacey 2001).

Bush's executive order against funding international abortion counseling was a typical order in several respects. Beyond automatically enacting his preferred policy, which after all is the primary function of an executive order, it was also an instance of one presidential directive overriding a previous presidential directive, and many directives early in a new administration do this (Mayer 2001, 88-89). Furthermore, the order had a symbolism beyond its substance, as it made an ideological point and appealed to a key group in the president's political base, as many other presidential directives do.

Bush also used the president's unilateral powers for a related issue, namely the use of fetal tissue for stem cell research. In August 2001, the Bush Administration promulgated a rule that limited embryonic stem cell research to the 78 lines of stem cells that already existed, preventing federal 
funds from being used to destroy more embryos. In 2006, Bush used the first veto of his presidency to block a congressional attempt to loosen his restriction. Then on June 20, 2007, he vetoed a similar measure and also issued an executive order encouraging other forms of stem cell research that did not destroy human embryos. Bush's use of a unilateral directive to block Congress and to make a politically symbolic point was very much in keeping with many previous unilateral directives. And his two immediate predecessors also used executive orders for this subject: George H.W. Bush issued an executive order in 1992 to establish a bank of fetal tissue obtained from ectopic pregnancies and spontaneous abortions, and Clinton issued an executive order in 1993 to lift a federal ban on research involving tissue from induced abortions.

Organized labor is another policy area in which Bush used unilateral directives in a more or less typical fashion. For example, Bush had occasion to issue several executive orders to create an emergency board to investigate labor disputes. But he also used unilateral directives to substantially alter labor policies. On February 17, 2001, just four weeks after being sworn in, Bush issued three executive orders concerning organized labor, once again to reverse policies that Clinton had established by executive order. Bush issued two executive orders to rescind Clinton's establishment of labormanagement councils in unionized federal workplaces. He also issued an executive order banning "project labor agreements," which can require contractors in federally funded projects to follow union standards. And he reinstated his father's requirement that federal contractors post notices of workers' right to a refund of union fees used for political purposes (Branum 2002, 47). ${ }^{3}$ Like his early directives for abortion and related issues, Bush's early executive orders about labor were intended not only to entrench his own priorities but also as a sort of ideological signal; the policies that he enacted had a symbolism beyond the immediate issues themselves.

For the past several decades presidents have often turned to unilateral directives for environmental policy, and Bush did so on several occasions. For example, in 2006 Bush issued proclamations to create new national monuments: in February he created the African Burial Ground National Monument on one-third of an acre in lower Manhattan, and in June he created the 140,000 square-mile Northwestern Hawaiian Islands National Monument. The proclamations themselves were not unusual, as presidents had issued dozens of similar proclamations to designate national monuments, pursuant to the 1906 Antiquities Act. What was unusual was that Bush did not issue more such proclamations, as most presidents have made much greater use of this authority.

In July 2008, Bush lifted an executive order that his father had signed in 1990, which had banned offshore oil drilling. Bush had long supported a 
repeal of the law against drilling, and his reversal order came during a time of record high gasoline prices and shortly after Republican presidential candidate Senator John McCain endorsed offshore drilling. However, Bush's order was merely symbolic, as a 1981 federal law bans offshore drilling, and in this regard as others, the will of Congress trumps an executive edict. Still, it remains a prime example of the use of unilateral directives for symbolic and signaling purposes.

In early 2007, two months after the Supreme Court ruled that the Environmental Protection Agency (EPA) should monitor greenhouse gas emissions from motor vehicles, Bush issued executive order 13,432 to govern their regulation. The order also called for federal agencies to use less gasoline and to increase alternative fuel use, but the order was important chiefly because it called for the EPA and the relevant departments to cooperate in protecting "the environment with respect to greenhouse gas emissions ... in a manner consistent with sound science, analysis of benefits and costs, public safety, and economic growth.”

The order was historic, but it was also typical in some respects. First, it was essentially mandated by the judiciary, and many unilateral presidential directives result from legislative or judicial requirements or prompts. Second, new policy areas are often first addressed by unilateral presidential directives and only later by Congress. Third, the order may have served to prevent or delay alternative actions, as California and other states had pushed for more rigorous regulations. There is along history of presidents using executive orders to thwart more stringent actions, for example as Ronald Reagan sought to do regarding harsh economic sanctions against apartheid South Africa in 1985.

Bush also used unilateral directives for governmental regulation more generally. In January 2007, shortly after the newly Democratic 110th Congress began, Bush issued executive order 13,422 to give the White House more say on regulatory policy, by having a political appointee in each agency supervise the development of new rules and regulations. The order also stipulated that in deciding whether to make regulations, federal agencies must identify a "specific market failure" that justifies the regulation. And it required agencies annually to estimate "the combined aggregate costs and benefits of all its regulations,” not just for each individual rule (Pear 2007).

Bush's executive order for regulation may appear significant, and indeed it constituted an important means of controlling federal regulatory actions. However, it was not unprecedented. For example, in 1980 Ronald Reagan issued an executive order 12,291, which sought to curtail governmental regulation by shifting the regulatory control from the agencies to the Office of Management and Budget (OMB) and the White House and also by requiring that the benefits of any new regulation outweigh its costs. And Bill 
Clinton issued executive order 12,886 in 1983 to impose a less strict test on new regulations, by requiring that their benefits justify (but not necessarily outweigh) their costs. While Bush's order similarly adjusted the cost-benefit criterion, however, it differed from these earlier orders by also ensuring that the decisions would involve people sympathetic to the president's point of view, rather than career public servants. Yet in another respect, Bush's order may be seen as typical or regular, in that it served to send a signal to the newly Democratic Congress that the president remained relevant. By some accounts, Bill Clinton's use of executive orders after the Republican ascendancy in the House and Senate in 1994 served the same purpose (Jehl 1994).

\section{Rare}

While the above unilateral directives arguably fit into the category of "regular" or normal directives, many of Bush's other directives were less typical, more unusual, or even rare. Fewer of Bush's directives fall into this category than the above category, but Bush issued many directives that in some sense departed from the norm. This may be seen by briefly considering Bush's general attitude towards his predecessor's unilateral directives and some of his own directives for faith-based initiatives, economic sanctions, presidential records, and congressional earmarks.

As we have seen, Bush issued several directives early in his first term to reverse some of Bill Clinton's own unilateral directives. But when conservative critics became upset over some of Clinton's late-term directives, some began to push for a more thorough rejection of Clinton's directives. After the disputed 2000 presidential election was decided but before he took office, Bush signaled that he intended to reverse many of Clinton's executive orders. His administration-in-waiting even threatened to systematically reverse all of Clinton's so-called "last-minute" executive orders, perhaps by halting the publication of The Federal Register, in which executive orders and proclamations are made public. While it is not unusual for a new president to issue unilateral directives to reverse the previous president's unilateral directives, the threat to do so systematically is unusual. Ultimately Bush shied away from this and adopted a more piecemeal approach (Mayer and Price 2002, 370). Thus, the idea of systematically reversing dozens of one's predecessor's directives with a single stroke of the pen remains just a possibility at present, albeit a striking one.

Other striking Bush directives were made a reality. For example, in his first week in office, Bush issued two executive orders to launch his "faithbased" service initiative, a major component of his "compassionate conservative" agenda. The orders established the White House Office of Faith-Based and Community Initiatives and directed agencies to investigate 
how faith-based groups could participate in federal programs. Bush sought legislative sanction for his policy, but after legislation on faith-based initiatives stalled in the Senate, the president again acted unilaterally. In December 2002, Bush issued two executive orders that included many aspects of the failed legislation. One order made it easier for religious organizations to get federal funding for charitable services by requiring that they be accorded "equal protection of the laws" and not be discriminated against just for being religious, and the other order established two centers for faith-based initiatives within the federal bureaucracy. In 2004, Bush built upon this by issuing executive order 13,342 to create centers for faith-based programs in other departments.

Bush's faith-based directives were not the first time that a president turned to unilateral directives to create a new program and office to prompt Congress. For example, John Kennedy created the Peace Corps by executive order in 1961, just two months after he took office. Congress then approved the Peace Corps and made it permanent a year and a half later. Similarly, Bush issued executive order 13,228 on October 8, 2001, to establish the Office of Homeland Security. The office later merged with the Department of Homeland Security which Congress created in 2002. But Bush's directives for faith-based initiatives differed from these other examples in that they raised a number of serious constitutional concerns about the separation between church and state, as his orders permitted religious groups to receive federal funds even if they based their hiring decisions on people's religious beliefs. Furthermore, Bush signed the second pair executive orders in a setting that closely resembled that of a traditional bill signing ceremony, as if they were regular pieces of legislation. Executive orders are just as legally binding as laws, but they are not the same, and Bush's signing ceremony intentionally blurred that distinction.

Economic sanctions are another area in which Bush's unilateral directives pushed the limits of established practice. Bush used executive orders to impose economic sanctions on foreign nationals whom he deemed to have aided terrorism or engaged in political activities adverse to U.S. interests. These directives froze individuals' assets and prohibited them from doing business with U.S. persons. By one estimate, several thousand people were targeted by these directives, including 475 people covered in a single executive order issued shortly after 9/11 (Whitelaw 2007). In addition to individuals suspected of aiding terrorism, targets included members of Saddam Hussein's regime, the government of Zimbabwe, forces involved in the Darfur conflict, and people who sought to undermine the sovereignty of Lebanon. Additionally, in July 2007 Bush issued executive order 13,438 to authorize freezing the assets of any one deemed to threaten the stability of Iraq, a rather poorly defined and broad group. Other presidents issued 
similar orders, but their measures targeted entire regimes rather than specific individuals, at least before Bill Clinton. And Bush issued many more of these directives than his predecessors (Whitelaw 2007). In addition to instituting individual economic sanctions, Bush issued several proclamations to bar officials from certain uncooperative governments (e.g., Belarus and Zimbabwe) from immigrating to the U.S.

Another early term executive order also shows how Bush's directives at times departed from the norm. In early November 2001, Bush issued executive order 13,233 , making private many presidential records that had previously been publicly accessible, including some of his father's records. Bush's order altered policies established by the Presidential Records Act of 1978, under which presidential papers become publicly available twelve years after the end of an administration, except for materials related to national security. The order set forth additional reasons that documents could be kept secret, it stipulated that the current president can make a previous president's papers secret even if the previous president objects, and it raised the legal bar for individuals seeking to challenge the designation of presidential documents as secret. The executive order was striking, and it fit with the Administration's broader concern for greater secrecy. ${ }^{4}$

Bush's executive order on presidential papers was not altogether unprecedented. In fact, in 1989 Ronald Reagan had used an executive order to restrict the public access of presidential documents beyond what the 1978 law provided. But even if Bush's order on presidential documents was not the first, it was nevertheless very controversial. Former President Bill Clinton publicly objected to Bush's order. The order was also formally contested by various academic groups, including the American Political Science Association (APSA), whose members often engage in archival research on presidential papers. And in 2007, part of the order was struck down by the D.C. district court, on the grounds that it went against the will of Congress, as expressed in the 1978 act.

With just a year remaining in his presidency, Bush again acted to thwart the will of Congress. In January 2008, after months of threatening, Bush issued executive order 13,437 to nullify congressional earmarks, by which individual lawmakers designate funds for projects in their home states or districts. The practice had long been controversial, and at the time of Bush's order the federal budget contained over 9,000 such projects, totaling roughly $\$ 7$ billion. Earmarks became an issue in the 2008 presidential campaign, and Bush's action appealed to fiscal conservatives and others who decried wasteful government spending.

Even before it was formally issued, Bush's order was controversial both constitutionally and politically. For some critics it raised constitutional concerns about possible executive infringement on Congress's legislative 
prerogatives. However, a memo prepared by the Congressional Research Service (CRS) nine months before the order was issued said that such an order would be permissible, as 95 percent of FY2006 earmarks were not part of the legislation itself but rather contained only in the committee reports and hence not legally binding (CRS 2006). The CRS memo thus assuaged constitutional concerns, but it then raised a political concern, as it stated: "Practical political considerations as well as notions of comity between the legislative and executive branches, however, may serve to encourage compliance with these directives [i.e., earmarks], despite the fact that as a matter of law they are not binding” (CRS 2006). In short, even if the order would be constitutional, it might be politically inadvisable.

Indeed, despite their at times unseemly nature, congressional earmarks had long been an important aspect of the politics of the policymaking process. Earmarks can be especially important in an election year, as members of Congress seek to demonstrate to their constituents that they can bring home federal money. Perhaps for this reason, the Democratic and Republican leaders of the Senate Appropriations Committee both called on the president not to issue the order. Democrats were particularly angered that Bush did not make such an issue of earmarks when Republicans controlled Congress (Bogardus and Raju 2008). Nevertheless, Bush issued the order.

Bush's earmark order was certainly dramatic, but it was not altogether unprecedented. For example, in 1988, the Reagan Administration attempted something similar. The Director of OMB, Jim Miller, sent a memo to federal agency heads advising them that they did not have to spend money on earmarks contained in congressional committee reports. However, Miller had to back down when many members of Congress complained (Bogardus and Raju 2008). Congressional complaints have not yet negated Bush's executive order. In May 2008, the House Armed Services Committee sought to place language in a defense authorization bill that stipulated that Bush's ban on earmarks would not apply to the reports accompanying that particular bill. It remains to be seen how Congress will respond to Bush's order against earmarks, but one option is for Congress simply to place future earmarks in the legislation itself, such that they will be legally binding and exempt from the order.

\section{Remarkable}

As the first two categories demonstrate, Bush's unilateral directives have been both regular and rare, both normal and unusual. In other words, some have been very much in keeping with previous presidents' precedents, while others have been somewhat more novel. However, some of Bush's 
unilateral directives have gone beyond this second category and have been dramatically different, truly remarkable, or even radical.

Many of Bush's more controversial orders have concerned the "War on Terror," and many of those directives arguably fit in this category. But it is important to realize that many of Bush's anti-terrorism directives were not radical. For example, Bush's proclamation of a national emergency three days after the 9/11 attacks was perhaps not unusual given the situation, and his subsequent executive orders to track and freeze financial assets that might abet terrorism may fit into the category of rare or unusual, but they were not revolutionary. Similarly, the two memos that Bush issued in the summer of 2005 to ensure inter-departmental sharing of information and effective communication between the FBI and the CIA were unusual and perhaps unprecedented but not altogether radical, given the circumstances.

However, other directives concerning the war on terror were much more audacious and controversial. For example, journalists have claimed that Bush used a number of executive orders to facilitate secret military action against terrorists in foreign countries. According to Seymour Hersh, "The President has signed a series of findings and executive orders authorizing secret commando groups and other Special Forces units to conduct covert operations against suspected terrorist targets in as many as ten nations in the Middle East and South Asia” (Hersh 2005). Similarly, the New York Times reported in November 2008 that Bush promulgated a classified order in the spring of 2004, by which the U.S. military and C.I.A. carried out nearly a dozen attacks in Pakistan, Syria, and other countries (Schmitt and Mazzetti 2008b). And in September 2008, the New York Times reported that Bush secretly approved orders in July to allow U.S. Special Operations forces to conduct ground attacks within Pakistan, without first obtaining the approval of Pakistani authorities, who are ostensibly U.S. allies (Schmitt and Mazzetti 2008a). At present, these directives are very much shrouded in secrecy, and they may be firmly grounded in the president's power as commander in chief and perhaps also in congressional authorization. But they are controversial both politically and constitutionally, and they invite unsavory comparisons with previous presidents' secret military operations, such as Richard Nixon's secret bombing of Cambodia and Ronald Reagan's support of the Nicaraguan Contras.

Another secret unilateral directive is reportedly behind a related controversial aspect of the war on terror, namely the assassination of certain foreign leaders. Bush reportedly signed a secret legal finding six days after 9/11 to authorize the CIA to kill some two dozen individuals who were mentioned by name but whose identity has been kept a secret. Osama Bin Laden and top Al Queda and Taliban officials were presumably among those on the list, but there is no way to know. Bush's directive selectively over- 
rode the ban on assassination that Gerald Ford enacted by executive order in 1976, after Senate hearings documented numerous U.S. attempts to kill foreign leaders. Ford's order prohibited any U.S. government agency or employee from participating in or planning an assassination. It has remained the law of the land ever since, and some subsequent presidents have even taken the symbolic but legally unnecessary step of reaffirming it. Bill Clinton reportedly issued a "presidential decision directive" to authorize lethal force against AlQueda, and Bush's order may have built upon that, as it apparently did not altogether cancel Ford's order but rather singled out individuals as exceptions to it. By some accounts, Bush's assassination directive was merely part of a broader directive or set of directives that became known as the GST program, which permitted the CIA to surveil and capture suspects and to engage in "extraordinary rendition" by moving suspects to secret prisons in foreign countries in order to be interrogated (Priest 2005). To its many critics, this amounts to "outsourcing torture" (J. Mayer 2005).

Bush has used controversial unilateral directives to direct the war on terror at home as well as abroad. In December, 2005, U.S. citizens and politicians alike were shocked to learn that Bush issued an executive order for the National Security Agency (NSA) to engage in domestic spying. Bush had secretly issued the order in 2002, as part of the government's effort to prevent another 9/11-scale terrorist attack. There is a long history of domestic spying in the U.S., for example involving the FBI and suspected Communists or civil rights activists in the 1950s and 1960s. But Bush's policy seemed to directly contradict the legal processes set forth by the Foreign Intelligence Surveillance Act (FISA) of 1978, which required that the government obtain a warrant before domestic spying could commence. The New York Times broke the story on December 15, 2002, against the wishes of the Bush Administration, but after sitting on the story for a year. Public indignation at Bush's policy was immediate and widespread.

In the halls of Congress, Senators and Representatives were incredulous about Bush's unilateral spying program. The day after the story broke, the Senate refused to reauthorize the Patriot Act. Senator Arlen Specter (RPA) threatened to hold hearings, Senator Russell Feingold (D-WI) sought to pass a resolution censuring the President Bush for his actions, and some even spoke of possible impeachment. Criticism of Bush's executive orderdriven policy even came from members of the Bush Administration itself. On New Year's Day, 2006, the New York Times reported that in March 2004, acting Attorney General James Comey decided the program was likely unconstitutional and decided not to renew approval for it. Chief of Staff Andrew Carr and White House counsel Alberto Gonzalez then made a dramatic visit to the hospital bed of Attorney General John Ashcroft, who was recovering from gallbladder surgery, in a fruitless attempt to gain his 
approval. The White House then decided to continue with the program without the Justice Department's approval, though Bush later made undisclosed changes to the program (Eggan and Kane 2007).

In August, 2006, the judiciary also condemned Bush's order in ACLU v. NSA (2006-07). District Court Judge Anna Diggs Taylor invoked the Court's dramatic rejection of Harry Truman's seizure of the steel industry in Youngstown Sheet \& Tube Co. v. Sawyer (1952) and determined that Bush's policy violated the First and Fourth Amendments, the Administrative Procedures Act (APA), and FISA, thus invoking both of the traditional constraints on unilateral presidential directives: Congress and the Constitution. However, the case then went to the Sixth Circuit Court of Appeals, which in July 2007 dismissed it on the grounds that the plaintiffs had no standing, since they were unable to demonstrate that they had been subject to government wiretapping. In February 2008 the Supreme Court refused to review this decision. Various groups are currently in the process of trying to establish evidence that they have been wiretapped, but until they do so, the appeals court's decision stands. Bush's spying order was clearly controversial and ranks among the most unusual and remarkable unilateral directives he issued. But despite being roundly criticized, Bush's domestic spying program was legitimated and rendered permanent when Congress passed legislation endorsing a version of it in 2007 and again in 2008, also granting communications companies immunity from lawsuits about it.

Perhaps the most controversial part of Bush's war on terror was his program of detaining and trying suspected terrorists. And unilateral directives were very much part of this. On November 13, 2001, Bush issued "Presidential Military Order 1," which called for the detention of suspected terrorists and provided for their possible trial by military tribunals, with limited legal recourse. Bush justified his action by invoking his authority as commander in chief and also the resolution that Congress passed on September 15, 2001 to authorize military force. Additionally, the White House defended the measure by noting various precedents for military tribunals, which the Supreme Court had approved as early as 1801 (Bumiller and Johnston 2001). The order was not secret and was published in the Federal Register like a regular executive order or proclamation. Nevertheless, Bush's order reportedly "stunned" Colin Powell and Condoleeza Rice and other top officials who were not consulted in advance about the policy, and it angered John Ashcroft and other officials who were consulted but who resisted it (J. Mayer 2006, 52; Pfiffner 2008, 99).

Bush's policy of detention without recourse to habeas corpus was deemed unconstitutional in three cases in the summer of 2004: Rasul v. Bush (and Al Odah v. United States), Hamdi v. Rumsfeld, and Rumsfeld v. Padilla. The three decisions were issued on the same day (June 28, 2004), and they 
contained a total of ten different opinions. Their narrow ruling was that Guantanamo Bay, Cuba was within U.S. jurisdiction and hence subject to its laws, which meant that the detainees held there by the U.S. military must be accorded some due process. More broadly, the decisions in these cases had the effect of sharply rebuking the Bush Administration for denying the clear provision of the writ of habeas corpus in the Constitution (Ball 2007). Furthermore, in her opinion in Hamdi, Justice Sandra Day O'Connor rejected the Bush Administration's conception of separation of powers.

In 2006, the Court again rejected Bush's detainee policy in Hamdan v. Rumsfeld. The Court issued six different opinions in this case and split 5-3, but once again the majority effectively rebuked Bush, for violating the will of Congress, the Constitution, the Uniform Code of Military Justice (UCMJ), and the 1949 Geneva Conventions. The majority found that the president had acted unconstitutionally by unilaterally creating military commissions without Congress's assent. According to legal scholar and former Solicitor General Walter Dellinger, "Hamdan is simply the most important decision on presidential power and the rule of law. Ever" (Dellinger 2006).

Bush then issued new directives to modify and clarify his policy, issuing an executive order about military commissions in February 2007 and an executive order about court martials in April 2007. Nevertheless, in June 2008, the Court issued yet another decision against the Bush administration's detainee policy. In Al Odah \& Boumediene v. Bush, the Court considered the Military Commissions Act (MCA) of 2006, through which the Administration and Congress sought to negate the Court's previous rulings about detention. Once again, the Court rejected Bush's policy and ruled that detainees had a right to challenge their detention via federal courts.

Beyond the detention and trial of suspected terrorists, there is also the issue of their interrogation, and here again Bush enacted his policies by unilateral directives. In February 2002, Bush signed a memo that exempted members of al-Queda from the protections afforded by the Geneva Conventions, although it did require the U.S. military to treat detainees "humanely" (Pfiffner 2008, 148). In 2003, the Bush Administration issued a pair of secret memos that explicitly endorsed extreme interrogation techniques like waterboarding. The memos were issued after CIA Director George J. Tenet requested them, and a year after the Department of Justice endorsed them (Warrick 2008). Bush issued another executive order on interrogation techniques in 2005. And in response to the MCA, Bush issued executive order 13,440 in July 2007, interpreting the Geneva Conventions so as to authorize extreme interrogation techniques.

With the end of the Bush Administration, courts may not strike down any more of Bush's unilateral directives for the war on terror, but some of those directives may yet be condemned in the court of public opinion. For 
example, Pulitzer prize-winning journalist Ron Suskind alleges that in the fall 2003 Bush issued a secret order to the CIA to fabricate connections between Iraq and al-Queda concerning weapons of mass destruction (WMD). According to Suskind, the Bush White House ordered that the CIA forge a letter to link Iraq to the $9 / 11$ attacks, so as to bolster Bush's rationale for invading Iraq. He alleges that the Bush order stipulated: “And the letter should as well say that Saddam Hussein has been actively buying yellowcake uranium from Niger with the help of al-Queda.” The Bush White House and CIA officials denied Suskind's charge, so this cannot at present be considered a true unilateral directive. But the possibility of such an extraordinary order is rendered plausible by Bush's many controversial, remarkable, and radical directives in the war on terror.

\section{Conclusion}

As the foregoing discussion indicates, George W. Bush issued a lot of noteworthy unilateral directives, of various types. But overall, was Bush's use of unilateral directives unprecedented, and what are its implications for his legacy? Like much of Bush's presidency, it depends on how one looks at it. In one respect, Bush's use of unilateral directives underscores the sense in which Bush was an unusual and perhaps even unique president. Bush's public image is in large part that of an arrogant unilateral leader intent upon imposing his own rash judgments on a resistant world. And his extensive use of unilateral directives and his many highly controversial directives may support that image.

But Bush's use of unilateral directives may also suggest that his presidency was not altogether unusual or different. This may be seen in several ways. First, despite the cries of some critics, Bush's use of unilateral directives was not entirely unprecedented. Some of his directives were indeed constitutionally radical, but as we have seen, only a few were truly radically new, and even some of the controversial ones built upon previous presidents' precedents. Second, Bush's usage of unilateral directives appears to follow the recent norm of presidents increasingly relying on presidential memoranda and measures other than executive orders and proclamations (cf. Cooper 2001, 127; Woolley and Peters 2008). This may be partly attributable to the nature of the war on terror, but it also reflects a broader historical trend. Third, Bush's presidency ended much as it started: just as Bush threatened to reverse many of Clinton's orders, similarly Barack Obama signaled a willingness to reverse many of Bush's orders early in his presidency. This represents a continuation of a long-standing pattern, but with the allegedly principled complaints about this process switching from those on the political left to those on the right. 
Regardless of the extent to which Bush's unilateral directives broke new ground, part of Bush's legacy will be greater public knowledge and awareness of unilateral presidential powers. Future presidents will certainly continue to issue unilateral directives for a variety of purposes and policies, but such actions will likely draw more attention than they did before Bush's presidency.

\section{NOTES}

${ }^{1}$ The American Presidency Project at the University of California, Santa Barbara is currently trying to catalogue presidential memoranda.

${ }^{2}$ Cf. Kenneth Mayer and Kevin Price's (2002) method of ascertaining the significance of executive orders by using mentions in the media.

${ }^{3} \mathrm{~A}$ federal judge overturned this last order, but it was then upheld by an appeals court: UAW v. Chao (2003).

${ }^{4}$ Bush's executive order 13,292 of March 2003 also made it easier to keep executive documents from public view, and it gave the Vice President a say in the process of blocking declassification.

\section{REFERENCES}

Ball, Howard. 2007. Bush, the Detainees, and the Constitution. Lawrence: University Press of Kansas.

Barilleaux, Ryan J. 1988. The Post-Modern Presidency. New York: Praeger.

Bazelton, Emily, and Chris Wilson. 2008. Ten To Toss. Slate.com, October 3. [Accessed December 3, 2008.]

Bogardus, Kevin, and Manu Raju. 2008. Bush earmarks plan roils Dems, fractures GOP. New York Times, January 15.

Branum, Tara L. 2002. President or King? The Use and Abuse of Executive Orders in Modern-Day America. Legis. 28 J. 1.

Bumiller, Elizabeth, and David Johnston. 2001. A Nation Challenged. New York Times, November 14.

Congressional Research Service. 2006. Earmarks in FY2006 Appropriations Acts. [Memo.] Washington, DC. March 6.

Cooper, Phillip J. 2002. By Order of the President. Lawrence: University Press of Kansas.

Cooper, Phillip J. 2001. The Law: Presidential Memoranda and Executive Orders: Of Patchwork Quilts, Trump Cards, and Shell Games. Presidential Studies Quarterly 31:1.

Dellinger, Walter. 2006. A Supreme Court Conversation. Slate, June 29.

Eggan, Dan, and Paul Kane. 2007. Gonzales Hospital Episode Detailed. Washington Post, May 16.

Edwards. Catherine. 1999. Clinton's Abuse of Executive Power. Insight On the News, December 13.

Hersh, Seymour M. 2005. The Coming Wars. The New Yorker, January 24. 
Howell, William G. 2003. Power Without Persuasion. Princeton, NJ: Princeton University.

Jehl, Nicholas. 1994. One Hand Tied, Clinton Offers the Other. New York Times, November 10 .

Lacey, Marc. 2001. House Panel Blocks Order Linking Money to Abortion. New York Times, May 3.

Mayer, Jane. 2005. Outsourcing Torture. The New Yorker, February 14.

Mayer, Jane. 2006. The Hidden Power. The New Yorker, July 3.

Mayer, Kenneth R. 1999. Executive Orders and Presidential Power. The Journal of Politics 61:445-66.

Mayer, Kenneth R. 2004. The Return of the 'King'? PRG Report XXVI, 2 Spring.

Mayer, Kenneth R. 2001. With the Stroke of a Pen: Executive Orders and Presidential Power. Princeton, NJ: Princeton University.

Mayer, Kenneth R., and Kevin Price. 2002. Unilateral Presidential Powers: Significant Executive Orders, 1949-99. Presidential Studies Quarterly 32:367-386.

Moe, Terry M., and William G. Howell. 1999. The Presidential Power of Unilateral Action. Journal of Law, Economics, and Organization 15:132-179.

Moe, Terry M., and William G. Howell. 1999. Unilateral Action and Presidential Power: A Theory. Presidential Studies Quarterly 29:850-873.

Neustadt, Richard E. 1960. Presidential Power. New York: John Wiley \& Sons.

Pear, Robert. 2007. Bush Directive Increases Sway on Regulation. New York Times, January 30.

Pfiffner, James P. 2008. Power Play. Washington, DC: Brookings.

Pious, Richard M. 1974. Is Presidential Power a 'Poison'? Political Science Quarterly 89:627-643.

Priest, Dana. 2005. Covert CIA Program Withstands New Furor. The Washington Post, December 30.

Relyea, Harold C. 1998. Presidential Directives: Background and Review. Congressional Research Service. Washington, DC July 16.

Rodrigues, Ricardo Jose Pereira. 2008. The Preeminence of Politics: Executive Orders from Eisenhower to Clinton. New York: LFB Scholarly Publishing LLC.

Schmitt, Eric, and Mark Mazzetti. 2008. Bush Said to Give Orders Allowing Raids in Pakistan. New York Times, September 11.

Schmitt, Eric, and Mark Mazzetti. 2008. Secret Order lets U.S. Raid Al Queda in Many Countries. New York Times, November 10.

Suskind, Ron. 2008. The Way of the World. New York: Doubleday.

Warber, Adam. 2006. Executive Orders and the Modern Presidency: Legislating from the Oval Office. Boulder, CO: Lynne Rienner.

Warrick, Joby. 2008. CIA Tactics Endorsed in Secret Memos. The Washington Post, October 15.

Whitelaw, Kevin. 2007. Does a 'Bad Actors' List Go Too Far? U.S. News \& World Report, September 3.

Woolley, John T., and Gerhard Peters. 2008. A New Data Set on Forms of Unilateral Presidential Action. Paper presented at the annual meeting of the American Political Science Association, Boston. 